Ann. Biol. anim. Bioch. Biophys., I973, 13 (I), 7-I5.

\title{
POSITIVE HYDRODYNAMIC INTERACTION BETWEEN SWIMMING BULL SPERMATOZOA
}

\author{
C. VAN DUIJN, Jr. \\ Biophysics Department, "Schoonoord", \\ Research Institute for Animal Husbandry, \\ Driebergseweg $10 \mathrm{~d}$, \\ Zeist, The Netherlands
}

SUMMARY

Photo-electric recordings of movement tracks of bull spermatozoa have been analysed for interaction effects. A positive hydrodynamic interaction could be demonstrated, the mean velocity of spermatozoa swimming in groups or shoals being higher than that of single specimens in I 7 I out of 257 recordings, $\mathrm{P}<10^{-6}$ (non-parametric test).

The means of the actual ratios of the velocities varied with the time of storage $(r=+0.956)$, but partial correlation analysis showed that this is not a real effect of ageing, but is due to the different time-dependence of the rates of change with time of the numbers and the mean velocities of normally moving spermatozoa.

Spermatozoa of bull, boar, ram, dog and some other mammals have a nearly flat profile, the shape of the boundary curve in normal specimens conforming closely to a curtailed folium of Descartes (VAn Duijn, rg6o $a$ ) or a strophoid (VAn Duijn, r $960 \mathrm{~b}$ ). Under normal physiological conditions mammalian spermatozoa display progressive movement in the fully activated state, combined with rotation along their longitudinal axis, which is due to hydrodynamical effects arising from the three-dimensionality of the tail-wave (TAYLOR, I952; RIKMENSPOEL, I957, I962, I965; Van Duijn, Van Rosmalen et Van Voorst, I966; Van DuIjn, I966 b). In highly concentrated sperm suspensions with high motile activity, as are commonly encountered in bulls, strong interactions between the spermatozoa are apparent, resulting in a mass movement generally known as " wave formation ".

TAYLOR (I95I, I952) appears to have been the first who applied hydrodynamical principles to the understanding of movements of microscopical organisms, including 
spermatozoa. According to his model calculations a positive hydrodynamic interaction between spermatozoa moving at close distance is to be expected, $i$. e. spermatozoa swimming in groups or shoals should be able to develop a greater mean velocity than similar specimens swimming by themselves. On the other hand, negative (repulsive) interactions occur, too, owing to the negative electrical potential of the boundary layer of any spermatozoon, as shown by electrophoresis experiments (NEvo, MICHAELI et SCHINDLER, I96I) and by electron microscopy (VERES, I968). Electrostatic interactions between charged glass surfaces and spermatozoa have also been demonstrated. In specific experiments the number of yawing bull spermatozoa swimming between positively charged glass slides was $\mathrm{I} .6 \pm 0.23$ times greater than in controls where the charge had been removed by means of a radio-active brush $(0.02>\mathrm{P}>$ o.or) (VAN DUIJN, Ig66 a).

If the distribution of spermatozoa in a seminal sample were completely random, any kind of interaction absent and the sample were invariant with time during the observational period, the spatial distribution as well as its fluctuation within a small region should follow the Poisson distribution. However, earlier observations by RIKMENSPOEL, (I957) yielded a standard deviation of the time fluctuation per spatial unit that was Io $p$. Ioo less than that expected for a Poisson distribution with bull spermatozoa, whereas recent investigations of human spermatozoa by VAN DUIJN, VAN VOORST and FREUND (I97I) even gave a standard deviation that was 26 \pm 7.4 p. Ioo less than the expectation for a Poisson distribution $(P=0.00002)$. However, the real spatial distribution at any moment of time had a standard deviation that was $4.8 \pm 2.2 \mathrm{p}$. 100 in excess of the Poisson expectation $(\mathrm{P}<0.05)$ in this human material, studied by kinemicrographic analysis. Although these deviations might at least partly be due to the effects of interaction, it must also be considered that the absolute requirement for obeyance to the Poisson distribution, that the system is invariant with time, is violated because during the measuring period the mean velocity decreases as well as the number of spermatozoa that are freely moving in the field, partly owing to immobilisation of some sluggish specimens and partly because a number of specimens is trapped at the border of the microchamber.

The investigations reported here were performed for obtaining direct information with regard to primary interactions between swimming spermatozoa of the bull.

\section{MATERIALS AND ME'THODS}

Ten ejaculates from ten Dutch-Friesian and red-and-white Meuse-Rhine-Yssel bulls, diluted in the range from I : Io up to I : 200 with ultramicroscopically clear egg-yolk - citrate buffer, were used in the entire investigation. Split samples were kept under different conditions (illuminated or in darkness) and subsamples taken at different times during several days in order to get a sufficiently large range of conditions with respect to variation of velocities and numbers of normally moving spermatozoa. Complete details of the specimen technique and the photo-electric method for obtaining recordings and their nomographical evaluation have been given in earlier papers (Van Dutjn et Rikmenspoel, ig6o; VAN Duijn, I961).

The tracks of spermatozoa that appeared either separated or in groups were measured and from these data the mean velocities were calculated directly. Arbitrarily the definition of group swimming was laid down as a sequence of signals at the recordings where at least the tail track of one specimen overlapped the head track of the next one. Any bias resulting from this definition would favour the null hypothesis that no interaction influencing spermatozoon velocity occurs. 
The diluted semen was stored at $2^{\circ} \mathrm{C}$, whereas all photo-electric recordings were taken at $37^{\circ} \mathrm{C}$. Two of the ten ejaculates were investigated during one day only; this series amounted to 24 recordings from 24 subsamples. Eight ejaculates from eight other bulls were followed over a five days period in order to investigate whether there would be any effect of ageing as well. The number of subsamples of the diluted semen in this series recorded on the first day amounted to 68 , on the second day $6 \mathrm{I}$ and on the third and fourth day 48 . A further recording of each of these ejaculates was taken on the fifth day. The data used in the analysis in relation to time (presented in fig. I) include the total data available from these same ejaculates, without any selection whatsoever. Of course, the 24 recordings from the two ejaculates that had been investigated on the first day only, were not included in the calculations in relation to the effect of time.

\section{RESULTS}

The mean velocity of spermatozoa swimming in groups (" groupies ") was higher than that of single specimens ("individuals ") in $\mathrm{r} 7 \mathrm{I}$ out of 257 recorded subsamples, lower in 85 and equal in I recording. This result is significantly in favour of the hypothesis of a positive interaction between spermatozoa, resulting in a higher mean velocity where they are swimming in groups, $\mathrm{P}<1 \mathrm{IO}^{-6}$ according to the (nonparametric) sign test.

The mean of the ratio $\bar{v}_{\text {groupies }} / \bar{v}_{\text {lndividuals }}$ increased with the age of the semen, the correlation coefficient being $r=+0.95^{6}, 0.02>\mathrm{P}>0.01$. The relevant data are presented in table $I$ and figure $I$.

The ratio of the two mean velocities (of the groupies and the individuals, respectively) was chosen instead of the difference, because the ratio is dimensionless and contains more relevant information than a difference, as well as to avoid before hand any necessity to correct for varying levels between ejaculates if these should occur. There is, however, no essential difference between the presentation of the ratios and those of differences ; since the ratios are equivalent to normalised differences this would only change the numerical scale.

Since the total number of normally moving spermatozoa as well as the mean velocities of those swimming either in groups or separately, decrease with time and each at a different rate, the further question is raised whether the time-dependence of the ratio $\bar{v}_{\text {groupies }} / \bar{v}_{\text {individuals }}$ could anyhow be really related with the age of the population or whether it might be due to the different rates of change of the separate parameters with time. Therefore, a partial correlation analysis was performed with the means of the parameter values of each age block as shown in figure I and table I.

In a partial correlation calculation at first one parameter is kept constant, then two parameters a. s. o., till all parameters that might have some relevance in the system have been kept constant. The parameters that have been kept constant do not influence the correlation coefficient anymore.

Because the number of normally moving spermatozoa decreases exponentially with time (RIKMENSPOEL, I957; VAN DuIJN et RIKMENSPOEL, I960 ; VAN Duijn, I96I, I962, I964, I965 a. o.) the correlation between the numbers of normally moving spermatozoa per unit of volume $(N)$ and time was calculated in the linearised form of $\log N=f(t)$.

The other characteristics were still in the linear region of their relationship with time, as is evident from figure I. This linearity is in agreement with earlier observa- 


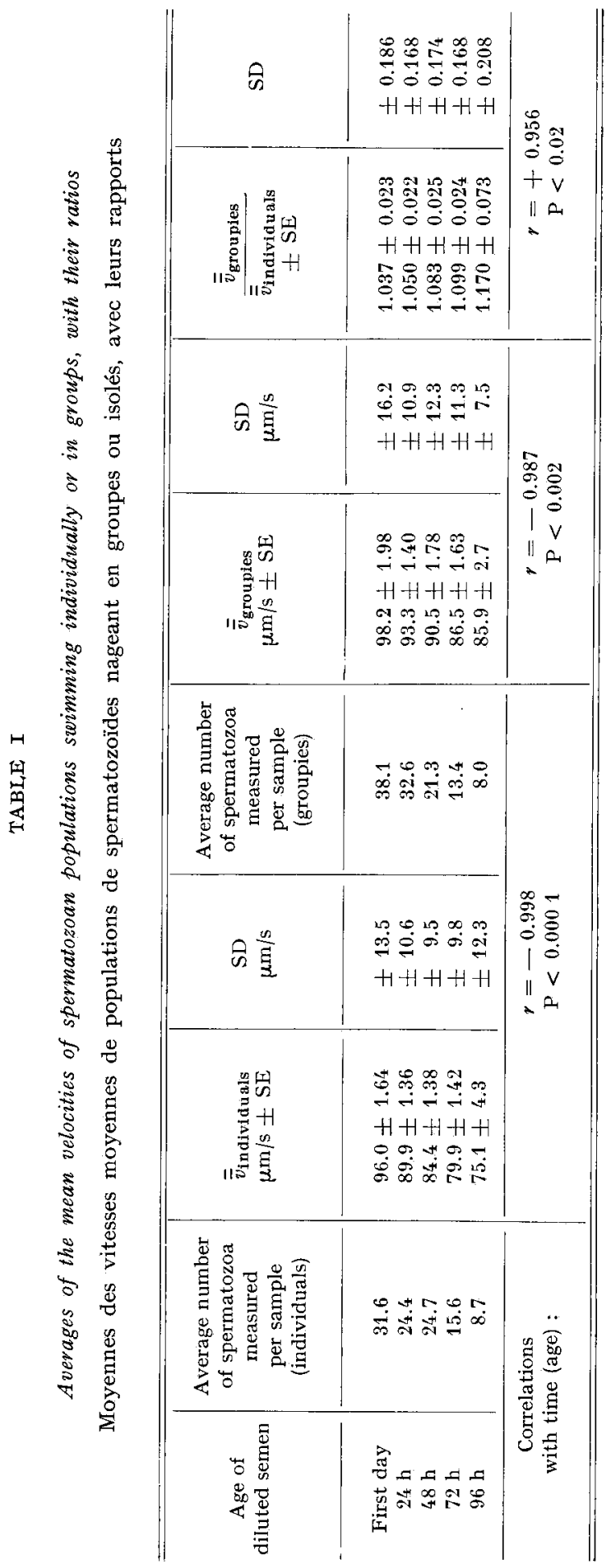




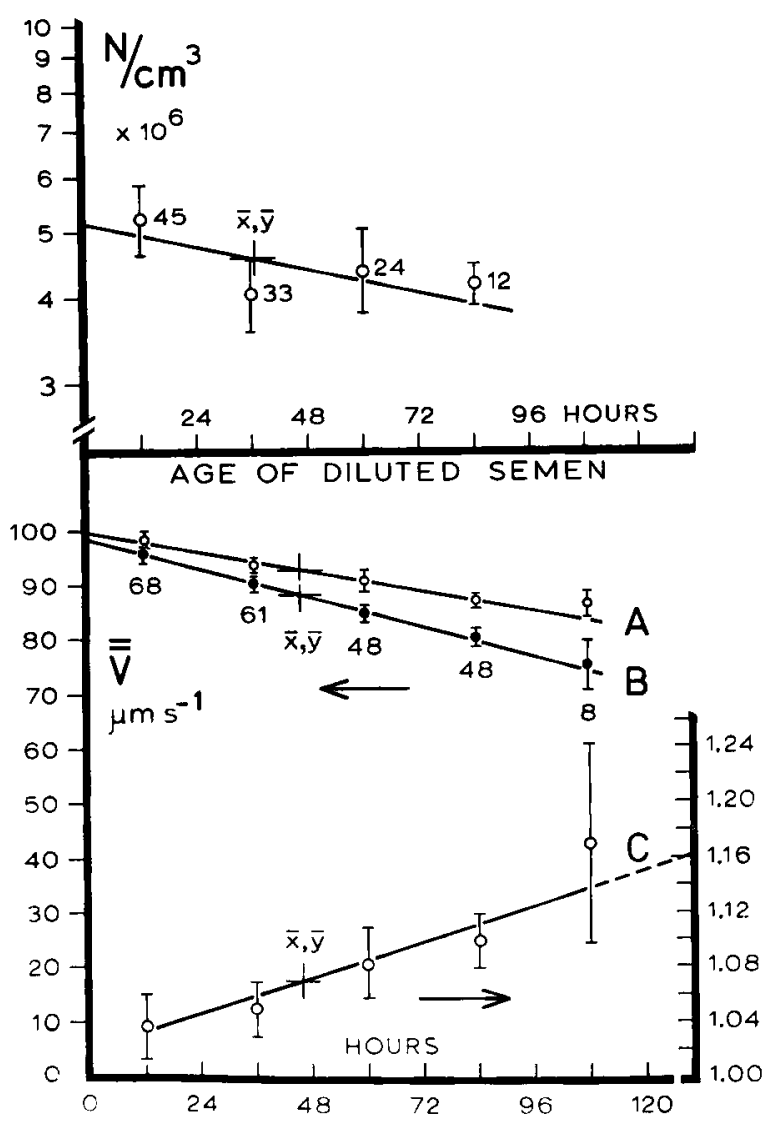

FIG. I. - Relationship between parametric values of interaction at $37^{\circ} \mathrm{C}$ and the period of storage at $2^{\circ} \mathrm{C}$

Upper graph: Decrease of numbers of normally moving sperms per unit volume during storage on a semilogarithmic plot (ordinate logarithmic). The figures near the data points indicate the numbers of recordings that have been measured and averaged.

Lower graph. A, B : course of the mean velocities with time, averaged over the number of separate recordings shown near the data points, curve A referring to the spermatozoa swimming at interaction distance ("groupies") and B to single sperms (" individuals"), in the same recordings.

Curve $C$ gives the course of the average of the ratio $\bar{v}$ groupies $/ \bar{v}$ individuals to be read at the right hand scale. If the figures of this scale are decreased by 1.0 each, the scale is transformed to a scale of normalised differences, for which the same regression holds.

\section{Relation entre les valeurs paramétriques de l'interaction à $37^{\circ} \mathrm{C}$ et la durée de conservation à $2^{\circ} \mathrm{C}$}

Graphique supérieur : Diminution du nombre de spermatozoïdes à déplacement normal par unité de volume pendant la conservation, exprimée en coordonnées semi-log (ordonnée logarithmique). $45:$ nombre d'enregistrements.

Graphique inférieur. A. B : Évolution des vitesses moyennes avec le temps. 68 : nombre d'enregistrements Courbe A : spermatozoïdes nageant en groupe ; courbe B ; spermatozoïdes isolés dans les mêmes enregistrements.

$\mathrm{C}$ : Évolution de la moyenne du rapport $\bar{v}$ groupes $\bar{v}$ individuels (échelle de droite). Si les nombres de cette échelle sont diminués de I,o chacun, l'échelle est transformée en une échelle de différences normalisées pour laquelle la même régression est maintenue. 
tions (VAN DUIJN, I962 and numerous later, unpublished, measurements) covering data obtained with bull semen stored at $\sim 2^{\circ} \mathrm{C}$, special adverse conditions being absent. This linear relationship is part of a more general ageing function (VAN DUIJN, I962) which did not yet show in the present investigation, obviating the need for a special discussion. The high values obtained for the coefficient of correlation demonstrates the high degree of precision of our present-day biophysical methods for measuring spermatozoan velocities as well as the scatter-reducing effect of using the mean values over all subsamples of the same series of ejaculates. Blocking data improves the reliability of a functional analysis, although this advantage is paid for by a reduction of the number of degrees of freedom.

TABLE 2

Partial correlation analysis of interaction data with respect to time-dependance of the velocity ratios

Analyse des corrélations partielles des interactions en tenant compte de la dépendance par rapport au temps de conservation des rapports des vitesses

\begin{tabular}{|c|c|c|}
\hline Correlation & $\begin{array}{l}\text { Correlation } \\
\text { coefficient } r\end{array}$ & Significance $\mathrm{P}$ \\
\hline $\begin{array}{l}\log N \times \text { time } \ldots \ldots \ldots \ldots \ldots \ldots \ldots \ldots \\
\bar{v}_{\text {Individuals }} \times \text { time } \ldots \ldots \ldots \ldots \ldots \ldots \ldots \\
\frac{\bar{v}_{\text {groupies }} \times \text { time } \ldots \ldots \ldots \ldots \ldots \ldots}{\bar{v}_{\text {groupies }}} \bar{v}_{\text {individuals }} \times \text { time } \ldots \ldots \ldots \ldots \ldots \ldots\end{array}$ & $\begin{array}{r}-0.82 \\
-0.99 \\
-0.98 \\
+0.95\end{array}$ & $\begin{array}{l}<0.05 \\
<0.001 \\
<0.001 \\
<0.01\end{array}$ \\
\hline $\begin{array}{l}\frac{\bar{v}_{\text {groupies }}}{\bar{v}_{\text {individuals }}} \times v_{\text {individuals }} \ldots \ldots \ldots \\
{\left[\left(\bar{v}_{\text {gr }} / \bar{v}_{1 \text { ind }}\right) \times \bar{v}_{\text {ind }}\right] N \ldots \ldots \ldots \ldots \ldots} \\
{\left[\left(\bar{v}_{\text {gr }} / \bar{v}_{\text {ind }}\right) \times \bar{v}_{\text {ind }}\right] \text { time } \ldots \ldots \ldots \ldots \ldots} \\
{\left[\left(\bar{v}_{\text {gr }} / \bar{v}_{\text {ind }}\right) \times \bar{v}_{\text {ind }}\right] \text { time }, N \ldots \ldots \ldots \ldots}\end{array}$ & $\begin{array}{r}-0.94 \\
-0.84 \\
+0.01 \\
-0.01\end{array}$ & $\begin{array}{c}<0.02 \\
<0.05 \\
\mathrm{NS} \\
\mathrm{NS}\end{array}$ \\
\hline $\begin{array}{l}\left(\bar{v}_{\mathbf{g r}} / \bar{v}_{\text {ind }}\right) \times \log N \ldots \ldots \ldots \ldots \ldots \ldots \\
{\left[\left(\bar{v}_{\mathrm{gr}} / \bar{v}_{\text {ind }}\right) \times \log N\right] \text { time } \ldots \ldots \ldots \ldots \ldots} \\
{\left[\left(\bar{v}_{\mathbf{g r}} / \bar{v}_{\text {ind }}\right) \times \log N\right] \bar{v}_{\text {ind }} \ldots \ldots \ldots \ldots} \\
{\left[\left(\bar{v}_{\mathbf{g r}} / \bar{v}_{\text {ind }}\right) \times \log N\right] \bar{v}_{\text {ind }}, \text { time } \ldots \ldots \ldots}\end{array}$ & $\begin{array}{l}-0.77 \\
+0.06 \\
+0.002 \\
+0.06\end{array}$ & $\begin{array}{l}\text { NS } \\
\text { NS } \\
\text { NS } \\
\text { NS }\end{array}$ \\
\hline 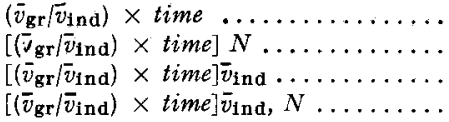 & $\begin{array}{l}+0.95 \\
+0.85 \\
+0.42 \\
+0.42\end{array}$ & $\begin{array}{c}<0.01 \\
<0.05 \\
\text { NS } \\
\text { NS }\end{array}$ \\
\hline
\end{tabular}

The relevant results of the partial correlation analysis are given in table 2 , where the factors that have been kept constant are indicated outside the parentheses. It should be understood that the analysis implies the theory of estimating rather than that of testing alternative hypotheses; since the time-dependant functions of the separate parameters are well known from extensive previous investigations, the only question to be answered here is to what degree the overall interaction effect between spermatozoa is really time-dependant, too, or only resulting from the different rates of change with time of the separate parameters, as stated before. 
In this respect, to some one the correlation of the ratio $\left(\bar{v}_{\text {groupies }} / \bar{v}_{\text {individuals }}\right)$ with $\bar{v}_{\text {individuals }}$ might appear trivial, if it were erroneously mistaken for a relationship of the type $(\mathrm{C} / x) \times x$, with $\mathrm{C}$ as a constant. Even then, however, no high product moment correlation coefficient $r$ would appear, because such a relationship is not linear, but hyperbolic. In reality, however, both $\bar{v}_{\text {groupies }}$ and $\bar{v}_{\text {individuals }}$ are stochastic variables with their own frequency distributions; consequently a model as $(\mathrm{C} / x)=f(x)$ does not apply. This also follows from the result of the partial correlation analysis, since as soon as time is kept constant, every partial correlation involving the ratio $\bar{v}_{\text {groupies }} / \bar{v}_{\text {individuals }}$ in this time-correlated series of data breaks down. That is the exact meaning of the total and partial correlation coefficients in table 2 . Further, accounting for the effect of $N$ decreases the value of the correlation coefficient and its significance level for the correlations between the ratio $\bar{v}_{\text {groupjes }} / \bar{v}_{\text {individuals }}$ and the mean speed of individuals $\bar{v}_{\text {individual }}$ and with time, respectively.

These results indicate that indeed the change with time of the numerical value of the ratio $\bar{v}_{\text {groupies }} / \bar{v}_{\text {individuals }}$ (and the same holds true for their difference) depends on the different rates of change of the separate parameters $\bar{v}$ and $N$ with time rather than on some direct effect of ageing on the spermatozoan population. This demonstrates that it is indeed a wise policy to apply non-parametrical statistical tests where deviations from normal statistical distributions may be expected, as has been done in the analysis of the interaction effect proper.

Because of the earlier observed anomalies of the statistical distribution (mentioned in the Introduction) it was further investigated whether there was any relationship between the mean velocities and sample size, respectively, and the standard deviations of the velocity frequency distributions. The results are offered in table 3 .

\section{TABLE 3}

\section{Correlation between standard deviations and sample means and number $\mathrm{n}$ of specimens sampled}

Corrélation entre les déviations standard et les moyennes des échantillons d'une part, et le nombre $n$ d'échantillons d'autre part

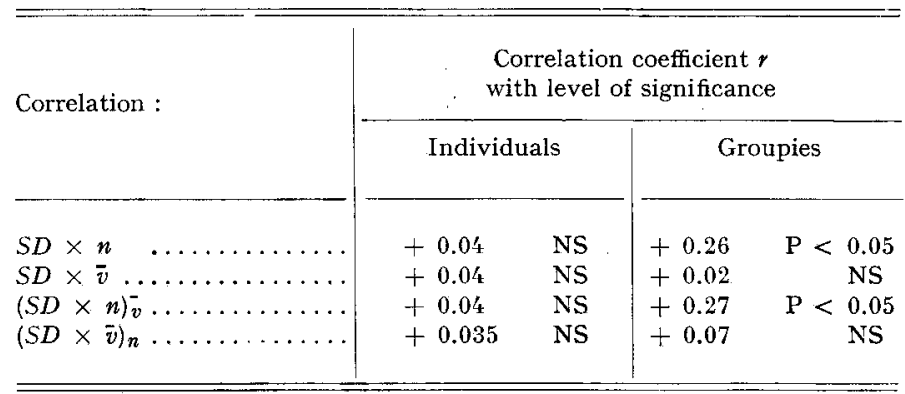

In the present data there is obviously no correlation between the standard deviation of $\bar{v}$ and sample size and sample mean of the individually swimming spermatozoa, whereas there is a significant positive correlation between the standard deviation of $\bar{v}$ and the sample size $n$ with the groupies. This might be connected with 
the degree of synchronization of tail movements and equalisation of the velocities of the specimens within a group, that will impose more stringent restrictions on the individual movements when the number of specimens in the group increases.

Synchronization of the tail beat in groups can be demonstrated most easily at the border of the microchamber, where sperms accumulate with their heads directed toward the boundary. However, direct observation of synchronized movements in the bulk of the sample is also possible in bull and boar semen diluted with egg-yolk - citrate media. Groups of $2-4$ sperms displaying completely synchronized rotatory movements along their longitudinal axes are encountered regularly. Direct recognition of this three-dimensional movement is greatly facilitated by the use of a truestereoscopic high-power microscope and application of stereokinemicrography (VAN DUIJN, I97I).

In the process of synchronization the repulsive Coulomb forces resulting from the surface charge of equal sign must play an important rôle to prevent the tails from touching each other with the consequent probability of adherence and agglutination. Any quantitative theory covering the interaction phenomena, especially those including mass interactions known as " wave formation " must duly consider the electrical as well as the hydrodynamical parameters of the system.

There was no significant difference between the variances of the velocity distributions $s_{v}^{2}$ of the individuals and the groupies (F-test).

According to the arbitrary definition of group swimming to be used with the photo-electric recording method, some specimens may erroneously have been included in the groups. As stated before, such bias favours the null hypothesis and hence they do not invalidate the significant results indicating positive interaction in the groups, although the numerical values might have become systematically lower than the (unknown) true ones.

Rę̧u pour publication en octobre 1972.

\title{
ACKNOWI,EDGEMENT
}

The author thanks his collegue $H$. W. Verver, Head of the Department of Mathematical Statistics of this Institute, for critical discussions.

\section{RÉSUMÉ}

\author{
INTERACTION HYDRODYNAMIQUE POSITIVE, \\ ENTRE SPERMATOZOÏDES MOBILES DE TAUREAU
}

L'enregistrement photoélectrique des déplacements des spermatozoïdes de Taureau a été analysé pour étudier les interactions possibles.

Une interaction hydrodynamique positive a pu être mise en évidence, la vitesse moyenne des spermatozoïdes nageant en groupes plus ou moins compacts étant plus élevée que celle des spermatozoïdes isolés dans $\mathrm{I} 7 \mathrm{I}$ sur 257 enregistrements $\left(\mathrm{P}<\right.$ IO $^{-6}$; test non-paramétrique). 
Les moyennes des rapports des vitesses varient avec le temps de conservation $(r=+0,956)$. Une analyse de corrélation partielle montre que ce n'est pas véritablement un effet du vieillissenent, mais que, avec le temps, l'évolution du nombre et de la vitesse moyenne des spermatozoïdes qui se déplacent normalement est différente.

\section{REFERENCES}

DUIJN C. VAN, Jr., I960 a. Mensuration of the heads of bull spermatozoa. Mikroskopie, 14, 265-276.

Duijn C. VAN, Jr., 1960 b. Mensuration of the heads of boar spermatozoa. Mikroskopie, 15, 142-156.

DuIjN C. Van, Jr., r96r. Photodynamic effects of vital staining with diazine green (Janus green) on living bull spermatozoa. Exp. Cell Research, 25, I20-130.

DuijN C. VAN, Jr., r962. Velocity characteristics and numbers of bull spermatozoa in relation to ageing, determined by photo-electric methods. J. Reprod. Fertil., 4, 277-29o.

Duijn C. VAN, Jr., I964. Het verband tussen aantal, beweeglijkheid en overlevingsduur van spermatozoa en de bevruchtingskans. Ned. Tijdschr. Genzesk., 108, I I16-1 I23.

Duijn C. VAN, Jr., I965. Relations entre les caractéristiques du sperme et la fertilité. Ann. Biol. anim. Bioch. Biophys., 5, 419-443.

DUIJN C. VAN, Jr., r966a. Normal and abnormal patterns of spermatozoan movement in relation to longevity and fertilizing power. Acta physiol. pharmacol. neerl., 13, 478-479.

DUIJN C. VAN, Jr., $1966 \mathrm{~b}$. The relationship between ultrastructure and movement patterns of spermatozoa, studied in model experiments. Proc. Vth World Congr. Fertil. Steril., Stockholm, I6-22 June I966, $63 \mathrm{I}-635$.

Durje C. VAN, Jr., I971. Mikrofotografie en mikrokinematografie. Focus-Elsevier, Amsterdam.

Duijn C. VAN, Jr., Rikmenspoel R., I96o. The mean velocity and velocity frequency distributions of normal bull spermatozoa at different hydrogen ion concentrations, derived from photo-electric measurements. J. Agric. Sci., 54, 300-309.

Duijn C. Van, Jr., Rosmalen W. Van, Voorst C. Van, ig66. Model studies of normal and abnormal movements of spermatozoa. Res. Film, 5, 623-64I.

Duijn C. Van, Jr., Voorst C. Van, Freund M., I97I. Movement characteristics of human spermatozoa analysad from kinemicrographs. Europ. J. Obstet. Gynec., 1, I2 I-1 35.

Nevo A. C., Michaeli I., Schindler H., r961. Electrophoretic properties of bull and of rabbit spermatozoa. Exp. Cell Research., 23, 69-83.

RIKMENSPOEL R., 1957. Photoelectric and cinematographic measurements of the "motility "of bull sperm cells. Thesis, Utrecht University. Drukkerij H. J. Smit, Utrecht, Netherlands.

Rikmenspoel R., I962. Biophysical approaches to the measurement of sperm motility. Spermatozoan Motility. Ed. D. W. Bishop, Publ. No. 72, AAAS, Washington, D. C., 13-29.

Rikmenspoel R., 1965. The tail movement of bull spermatozoa. Observations and model calculations. Biophys. J., 5, 365-392.

TAylor G., I95I. Analysis of the swimming of microscopic organisms. Proc. Roy. Soc. (Lond.), A 209, 447-46I.

TAYLOR G., I952. The action of waving cylindrical tails in propelling microscopic organisms. Proc. Roy. Soc. (Lond.), A 211, 225-240.

VERES I., I968. Negative electrical charge of the surface of bull sperm. Mikroskopie, 23, I66-I69. 